\title{
Research of Forecasting the Number of 3G Users Based the BASS Model
}

\author{
Xiaoping Liu,Linjie Li \\ Chongqing University of posts and telecommunications \\ dodo_315@163.com
}

\begin{abstract}
In this paper, the diffusion process of China's 3G users is researched based on the Bass model. The parameters of the Bass model are estimated with the recent number of $3 G$ users. By the diffusion of the future $3 G$ users simulated, the trends of 3G market in the next few years is predict, to look forward to help the behavior of operators and government decision-making .
\end{abstract}

\section{Keywords-Bass model, Forecast, The diffusion process}

\section{INTRODUCTION}

After the new product invented, often it was to be introduced into the economic life by a small part of people firstly, and then gradually adopted by more people, this process is called the diffusion of innovations[1] or the adoption process for new products by scholars[2].

Previous studies showed that different economic and cultural background of the market different types of new products, the diffusion rate is different. Jang, Dai, and Sung (2005) did a comparative study of different countries and regions in the mobile communications market diffusion curve. They found that the curve parameters were significantly different, causing differences is the role of network effects between the various markets[3].Therefore, the specialized research in product-specific market is necessary.

In the past, the forecasts of the promotion and sales of new products, we often use the following three models: Bass model, Gompertz model and the Logistic model.

Bass model is the most widely used, because of the model using a simple model structure parameter setting, which is a good explanation and guidance to product marketing.

The question of when China would issue $3 \mathrm{G}$ cellular licenses had been anybody's guess for several years. In January 2009, China awarded a TD-SCDMA license to China Mobile, a CDMA 2000 license to China Telecom and a WCDMA license to China Unicom. China Mobile had made a soft launch of $3 \mathrm{G}$ services based on TD-SCDMA in April 2008.

How does a firm survive under such turbulent conditions? Traditionally, mobile and land phone providers competed fiercely for new customers. As the Chinese market provides an increasing range of opportunities for consumers, what kind of level will $3 \mathrm{G}$ markets in the next few years develop into?
Yi Li

Chongqing University of posts and telecommunications dodo_315@163.com cquiliyi@163.com

This article will did an empirical analysis and prediction using the Bass model of diffusion of $3 \mathrm{G}$ communications market, to provide marketing of the $3 \mathrm{G}$ telecom operators.

\section{RESEARCH BACKGROUND}

Telecommunication Union (I TU) 198 5, there are three technical standards of the mainstream $3 \mathrm{G}$ proposed the concept of the world recognized by the ITU: the extension from the GSM W CDMA, the evolution from the CDMA One of the CDMA 2000 R \& D and China Datang TD-SCD MA. TD-SCDMA standard proposed making China the first real opportunity in the mobile communications industry to form a huge chain, China's telecommunications development in the history of a landmark and far-reaching impact.

Telecommunication companies are advancing technology tremendously. As a result, they face intense competition, including competition from sources not previously existing. Perhaps now here is this Competition more challenging than in China. The Chinese mobile Communications market is now the largest total market and remains fast-growing, dynamic, and vibrant. Over half a billion Chinese consumers own and use a mobile phone[6].The Chinese government's restructuring of state owned monopolistic telecommunication system and further deregulation has led to a more open and free market system[7].In January 2002 , the Chinese government changed policy, allowing four major telecommunication companies (China Mobile, China Netcom, China Telecom, and China Unicom) to offer fixed network telecommunication, mobile communication, and other basic Communication services. In 2008, China Railcom, China Mobile will merge, operating TD-SCDMA network, China Telecom and China Unicom's C network cooperation of CDMA2000, while China Netcom and China Unicom merged G network operator WCDMA, three new operators, but also access to full-service license .

The formation of China Mobile, China Unicom (China Netcom) and China Telecom three major national fullservice provider of the "three pillars" of the situation. Restructuring of the telecommunications industry to solve the Chinese mobile communications market can not accommodate the size of the problem over the $3 \mathrm{G}$ operators, but also the issuance of licenses for the $3 \mathrm{G}$ operators cleared the final hurdle.

January 7, 2009, the Ministry of Industry and Information Technology officially released to the mobile operator 3G licences, including access to China Mobile TD- 
SCDMA licence, received WCDMA licence China Telecom, China Unicom to obtain CDMA 2000 licenses. After the operators put 3000 million Yuan into network infrastructure, and on television, newspapers, street put a lot of advertising.

The operators will be fully engaged in more intense competition in the $3 \mathrm{G}$ market, and strive to establish competitive advantage of the enterprises in the early. Thus, in the market research and forecasting the future $3 \mathrm{G}$ market consumer trends, it is valuable to guide the operators to form a competitive development strategy. This is a current issue worth studying.

\section{THE BASS MODEL}

The Bass model is a classic new product diffusion models. Since this model was proposed by Frank M.Bass the first time, a large number of academic literature did a demonstrational test and expansion of the model[4]. It was also widely used in the actual decision-making. Therefore, we choose Bass model to study the diffusion of $3 \mathrm{G}$ users.

The Bass model assumes a particular product market, there are no repeat buyers, and each person's purchases are a unit, this purchasing number is equivalent to the product sales. This assumption and the diffusion of $3 \mathrm{G}$ mobile communication is very consistent, and its use is the number of $3 \mathrm{G}$ users.

Bass also assumed that when a new product was put into the market, the diffusion of their products affected by two factors. First ,external influence, the mass media. The second is the internal effect, that buyers propagandized to who did not buy. Frank M.Bass will divide the users into two groups, through the first ways to purchase products referred to as innovators (innovators), purchase products through a second pathway called imitators (imitators).

The main parameters of the Bass model are as follows:

$\mathrm{t}$ time

$x(t)$ the number of total consumption in t time

a Influence coefficient of innovation

b Influence coefficient of imitation

M market capacity

There are two basic expressions of Bass model as follows:

$$
\begin{aligned}
& \frac{d x(t)}{d t}=\left(a+b \frac{x(t)}{M}\right)(M-x(t)) \\
& x(t)=M \times \frac{1-e^{-(a+b) t}}{1+\frac{b}{a} e^{-(a+b) t}}
\end{aligned}
$$

As expression(2) parameter estimates associated with a certain assignment of $t$ independent variables and expression(1) parameter estimates unassociated with a certain assignment of $t$ independent variables, so this paper adopt the first expression to estimate the parameters,

\section{THE APPLICATION OF THE BASS MODEL IN THE 3GSUBSCRIBER MARKET}

\section{A. Sample data}

TABLE I. THE NUMBER OF 3 G USERS

\begin{tabular}{|l|l|l|l|l|l|l|l|l|}
\hline $\begin{array}{l}\text { Time } \\
\text { (month) }\end{array}$ & $\mathbf{0 9 . 1 2}$ & $\mathbf{1 0 . 1}$ & $\mathbf{1 0 . 2}$ & $\mathbf{1 0 . 3}$ & $\mathbf{1 0 . 4}$ & $\mathbf{1 0 . 5}$ & $\mathbf{1 0 . 6}$ & $\mathbf{1 0 . 7}$ \\
\hline $\begin{array}{c}\text { Users } \\
\text { (million) }\end{array}$ & 1325 & 1454 & 1606 & 1808 & 1960.8 & 2224.8 & 2520 & 2808 \\
\hline $\begin{array}{l}\text { Time } \\
\text { (month) }\end{array}$ & 10.8 & 10.9 & 10.10 & 10.11 & 10.12 & 11.1 & 11.2 & 11.3 \\
\hline $\begin{array}{l}\text { Users } \\
\text { (million) }\end{array}$ & 3111 & 3498 & 3864 & 4261.1 & 4705 & 5173.8 & 5598.9 & 6019.2 \\
\hline
\end{tabular}

Telecom operators began to develop 3G business in 2009 . The initial diffusion rate of $3 \mathrm{G}$ users is not high, because preparatory work for telecom operators focused on network construction. In 2010, the number of $3 \mathrm{G}$ users began to rise significantly. The paper collected the data from the end of 2009 to March 2011 as shown in Table I.

\section{$B$. The estimation of the parameters of the Bass model}

The estimation of the parameters of the Bass model is an important process, there are three important parameters in the Bass model, which are the influence coefficients of innovation $a$, the influence coefficients of imitation $b$ and the market capacity $M$. In theory, the parameter $M$ should be estimated by the diffusion process model, but the maximum number of users will not affect the initial growth rate in the early stages of $3 \mathrm{G}$ telecommunications market. Therefore, the market capacity is not determined by the initial phase of the data. In the paper, the market capacity is determined by Experts predicting. According to the Forum Session of " 3G Applications \& Developers Conference" in 2009, DengKuiBin, who is vice President of the repays market research company, said that from the potential size of $3 \mathrm{G}$ the market, china would be the world's largest potential 3G market. According to user survey of sanofi-aventis's 3G data by the end of last year, shows that the users who have $3 \mathrm{G}$ business needs and purchased desire will attain to 490 billion, accounting for $76 \%$ to the entire Chinese cell phone users.

In the SPSS analysis of the diffusion model of $3 \mathrm{G}$ users, the parameter $\mathrm{a}, \mathrm{b}$ of the Bass model is estimated by nonlinear least squares (NLS). According to Srinivasan and Mason (1986) recommendations[5], we set the initial value of the coefficient which are estimated by OLS In the NLS estimates. The fitting results of the Bass model about $3 \mathrm{G}$ users are as follows.

\begin{tabular}{|l|r|r|r|r|}
\hline \multicolumn{5}{|c|}{ Parameter Estimates } \\
\cline { 4 - 6 } $\begin{array}{l}\text { Para } \\
\text { mete }\end{array}$ & & & \multicolumn{2}{|c|}{$95 \%$ Confidence Interval } \\
\cline { 4 - 6 } & Estimate & Std. Error & Lower Bound & Upper Bound \\
\hline $\mathrm{a}$ & .001 & .001 & $-3.879 \mathrm{E}-6$ & .003 \\
$\mathrm{~b}$ & .089 & .009 & .068 & .109 \\
\hline
\end{tabular}


Correlations of Parameter Estimates

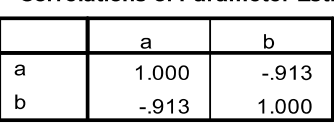

ANOVA $^{a}$

\begin{tabular}{|l|r|r|r|}
\hline Source & \multicolumn{1}{|c|}{$\begin{array}{c}\text { Sum of } \\
\text { Squares }\end{array}$} & \multicolumn{1}{c|}{ df } & \multicolumn{1}{c|}{$\begin{array}{c}\text { Mean } \\
\text { Squares }\end{array}$} \\
\hline Regression & 1624005.694 & 2 & 812002.847 \\
Residual & 27079.346 & 13 & 2083.027 \\
Uncorrected Total & 1651085.040 & 15 & \\
Corrected Total & 182050.797 & 14 & \\
\hline
\end{tabular}

Dependent variable: $y$

a. $R$ squared $=1-($ Residual Sum of Squares $) /($ Corrected Sum of Squares $)=$
851 .

After calculation, $\mathrm{a}=0.001, \mathrm{~b}=0.089, \mathrm{R} 2=0.851$.the results is acceptable, The results also found that the influence coefficients of innovation a is little. the influence coefficients of imitation is bigger than the influence coefficients of innovation. It shows that the role of word of mouth advertising is better than the role of mass media in the promotion of $3 \mathrm{G}$ users. Therefore, telecom operators should enhance brand reputation and service quality in the market competition.

C. the analysis of the bias of estimates

$$
\begin{aligned}
& \text { As } \mathrm{M}=49000, \mathrm{a}=0.001, \mathrm{~b}=0.089 \text {, the expression }(1) \text { is } \\
& \frac{d x(t)}{d t}=\left(0.001+0.089 * \frac{x(t)}{49000}\right)(49000-x(t))
\end{aligned}
$$

Setting the initial parameters by the date of December 2009 , the short-term time trend curve of $3 \mathrm{G}$ users could be got by Matlab simulation, as shown in fig 1 .

Since service quality and network stability in the market early, the actual values are lower than Estimates. After October 2010, the actual values are higher than Estimates because of increasing Market Development. Overall, the bias of estimates is acceptable.

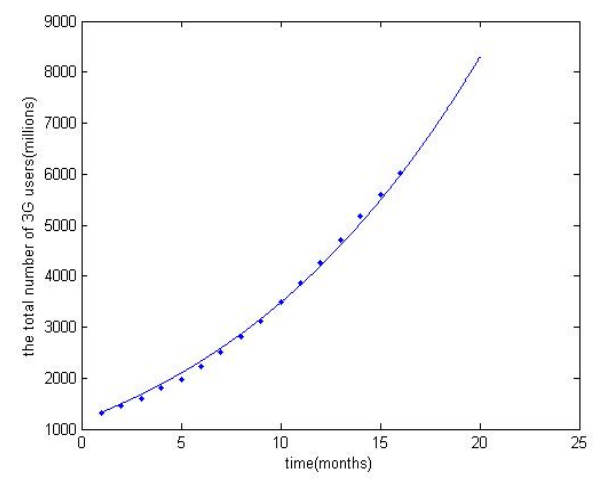

Figure 1. the bias of estimates

\section{The forecast of future sales}

Setting the initial parameters by the date of December 2009 , the long-term time trend curve of $3 \mathrm{G}$ users could be got by Matlab simulation, as shown in fig 2 .

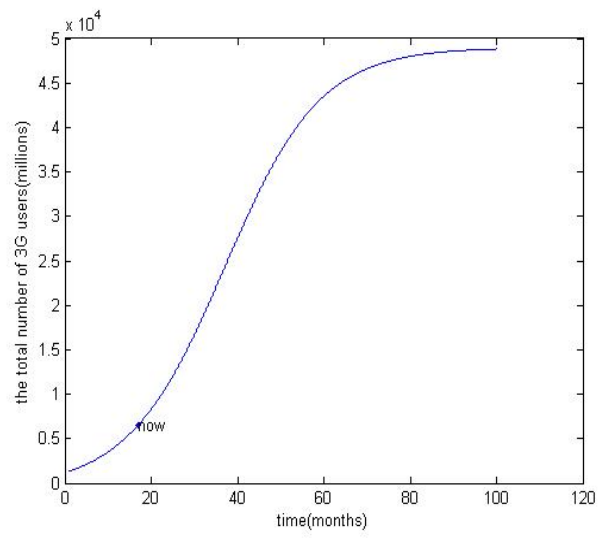

Figure 2. the long-term time trend curve of $3 \mathrm{G}$ users

Then the number of $3 \mathrm{G}$ users can be predicted as follow:

TABLE II. THE NEXT FEW MONTHS, THE FORECAST OF THE USERS

\begin{tabular}{|l|l|l|l|l|l|}
\hline $\begin{array}{l}\text { Time } \\
\text { (month) }\end{array}$ & $\mathbf{2 0 1 1 . 4}$ & $\mathbf{2 0 1 1 . 5}$ & $\mathbf{2 0 1 1 . 6}$ & $\mathbf{2 0 1 1 . 7}$ & $\mathbf{2 0 1 1 . 8}$ \\
\hline $\begin{array}{l}\text { Users } \\
\text { (million) }\end{array}$ & 6502.1 & 7064 & 7662.1 & 8297.2 & 8970.2 \\
\hline $\begin{array}{l}\text { Time } \\
\text { (month) }\end{array}$ & 2011.9 & 2011.10 & 2011.11 & 2011.12 & \\
\hline $\begin{array}{l}\text { Users } \\
\text { (million) }\end{array}$ & 9681.4 & 10431.3 & 11219.6 & 12909.9 & \\
\hline
\end{tabular}

AS shown in figure 2, the development of $3 \mathrm{G}$ communications market is near the first inflection in the $\mathrm{S}$ curve point at present, which is about to enter the market of scale expansion in the fast channel. In the next three years, $3 \mathrm{G}$ will be rapid growth period in China market, and will not be fully matured until 2014, from then on, the promotion speed will gradually decreased year by year. That means during the future three years time, the huge market of $3 \mathrm{G}$ will be the great opportunity to telecom operators.

\section{CONCLUSION AND PROSPECT}

In Using the Bass diffusion model, this paper carries on the analysis of the diffusion of $3 \mathrm{G}$ users. As the results, we find that predicted value correspond to actual value. So the diffusion model for China in the $3 \mathrm{G}$ users in marketing the forecasting is effective.

At present, China telecom industry is gradually turned from $2 \mathrm{G}$ to $3 \mathrm{G}$. From the major three operators starting in 2010,they make force of $3 \mathrm{G}$ products popularization. All operators are increasing competition among clients. According to this paper calculated, in the market promotion of $3 \mathrm{G}$ users, imitate influence coefficient value (through word-of-mouth dissemination to realize) is large than innovation influence coefficient value (through mass media to realize). Therefore, telecom operators can make a few placing messages ads to increase brand effect and more focus on the user's needs in the competition, to improve customers' satisfaction and brand reputation from itself quality and service. 
Meanwhile the surge in the future a large number of $3 \mathrm{G}$ customers, will lead the market for a variety of $3 \mathrm{G}$ valueadded services needs. It is foreseeable that the next few years will be the development of $3 \mathrm{G}$ value-added service providers a good opportunity.

In addition, in the upcoming stage of rapid development of $3 \mathrm{G}$, the government's actions will also greatly affect the future development of the three operators, thus TD-SCDMA, W-CDMA, CDMA2000, three different standards in the Chinese market to promote a corresponding impact. Government can also seek to introduce at this stage are conducive to the policy of TD-SCDMA, which can significantly increase the number of TD-SCDMA users, to help promote the domestic $3 \mathrm{G}$ standard.

In addition, in the Bass model, we can merge into $3 \mathrm{G}$ product market portfolio variables, especially such as product package and price competition factors, which can make the best products of the competition strategy.

\section{REFERENCES}

[1] Rogers E.M..Diffusion of innovations[M].New York:The Free Press, 1983.

[2] Gary L.Lilien,Philip Kotler and K.Sridhar Moorthy.Marketing models[M]. Englewood Cliffs,New Jersey:Prentice Hall,1992.

[3] Show-ling Jang,Shau-chi Dai and Simona Sung.The pattern and Externality effect of diffusion of mobile telecommunications: the case of the OECD and Taiwan [J].Information Economics and Policy,2005,17133-148.

[4] Bass F..A new product growth model for consumer durables[J].Management Science,1969,15:215-227.

[5] Srinivasan V.,Charlotte H.Mason.Nonlinear least squares sstimation of new product diffusion models[J].Marketing Science, 1986,15(4):169-178

[6] Nie W, Zeng H. The impact of China's WTO accession on its mobile communications market.[J]Bus Manag,2003,9(2):151-70.

[7] Wang Y, Lo H, Yang Y. An integrated framework for service quality, customer value, satisfaction: evidence from China's telecommunication industry. Inf Syst Front.2004,6(4):325-40. 